\title{
AUSTRALIAN LEGAL GEOGRAPHY AND THE SEARCH FOR POSTCOLONIAL SPACE IN CHLOE HOOPER'S THE TALL MAN: DEATH AND LIFE ON PALM ISLAND
}

\begin{abstract}
Sarah Keenan*
This essay reviews Chloe Hooper's non-fiction novel The Tall Man: Death and Life on Palm Island, a book about the 2004 death in custody of Cameron (who will hereafter be referred to as Mulrunji) ${ }^{1}$ Doomadgee on Palm Island in far north Queensland. After setting out the factual background to the death and its legal and political aftermath, I argue that The Tall Man is an original and important work that opens up the possibility for a space of Australian postcoloniality far more effectively than any of the legal proceedings surrounding the death did. I argue that the book can be described as a work of critical legal geography ${ }^{2}$ because it analyses the tensions between Australia's north and south, and traces the laws and state policies that continue to reproduce places of racial tension and violence. I further argue that Hooper's narrative provides an insightful depiction of the relation of white colonial patriarchy that is protected, reproduced and embodied by the Queensland police force. This relation of white patriarchy is one that has been associated with colonial policies since the beginnings of white Australia - from early policies of Indigenous genocide, to today's policies of saving Indigenous women and children from
\end{abstract}

Sarah Keenan is a PhD student at the Research Centre for Law, Gender and Sexuality at the University of Kent. Her research is funded by the University of Kent Law School and the Overseas Research Students Assistance Scheme. The author is hugely grateful to Sarah Lamble, Stewart Motha and two anonymous reviewers for their invaluable feedback on earlier drafts of this piece, and to Rose Cappello, Tal Core, Leigh Coonan and Gus Ky for engagements on these issues. Email: S.J.Keenan@kent.ac.uk

It is a custom in some Australian Indigenous communities to avoid directly naming a deceased person for a period of time after the death, as a mark of respect. Mulrunji was the name nominated by the family and means "the departed one", see footnote 1 of Boe Lawyers Final Submission on behalf of the Palm Island Aboriginal Council 4 July 2006 available at http://www.boelawyers.com.au/documents/Palm\%Island/Coronial\%inquest/PIAC\%20-

$\% 20$ Final \%20Submissions.04.07.06.pdf 3 (accessed 30 October 2008). Hooper notes that in fact the Indigenous witnesses in the Palm Island case continued to refer to the dead man as Cameron, with only the lawyers and journalists using Mulrunji, which she claims was consistently mispronounced, see Hooper Chloe The Tall Man: Death and Life on Palm Island Penguin Camberwell 2008. This claim is consistent with the family-supported memorial website for Mulrunji (www.myspace.com/mulrunji), which directs that the name is pronounced "moordinyi". I will continue to use the name Mulrunji for consistency and to avoid confusion, as all subsequent legal, media and academic coverage has used this name since the death. For more information on Indigenous communities and practices in the north east of Australia see Trigger David Whitefella Comin': Aboriginal Responses to Colonialism in Northern Australia Cambridge University Press Melbourne 1992.

2 For an overview of legal geography see Blomley Nicholas, Delaney David and Ford Richard T The Legal Geographies Reader: Law, Power and Space Blackwell Oxford 2001. 
Indigenous men. ${ }^{3}$ And it is a relation of white patriarchy that was momentarily threatened by the possibility that a white police officer might be held criminally responsible for the death of an Indigenous man in his custody. The Tall Man is in one sense a book that demonstrates Australia's failure to move to a space of "postcoloniality", by which I mean networks of relations, processes, experiences, and understandings that have departed from their colonial antecedents. ${ }^{4}$ In particular, Hooper makes clear the failure of the Australian legal system today to operate for indigenous people in a way that can be meaningfully distinguished from the way it operated for indigenous people in less post colonial times. But where Hooper finds a lack of postcolonial space in the Australian legal system, she strives in The Tall Man to find it somewhere else. Hooper does this by offering a narrative that attempts to encompass both indigenous and non-indigenous ways of knowing the world. While Hooper is explicit about writing the story from her perspective as a white woman from Melbourne, she also smoothly and respectfully weaves stories of Indigenous Dreaming into her narrative, most prominently the story of the Tall Man. Hooper's book is at once an account of Mulrunji's fatal encounter with Hurley and its aftermath, and a rendition of the Tall Man legend. It is a powerful and productive attempt to find a space of Australian postcoloniality.

\subsection{The Death of Mulrunji DoomadgeE}

Palm Island is a stunning tropical island accessible by a two-hour ferry ride or a forty minute charter flight from the mainland. The island is home to around 3000 residents, almost all of them indigenous. ${ }^{5}$ Local man Mulrunji was planning to go fishing on the morning of November 19, 2004. Thirty-six years of age, Mulrunji was a fit and healthy man, who prided himself on providing self-caught food for his family. ${ }^{6}$ Walking barefoot and "in a happy mood" having drunk a fair amount of alcohol with a friend the night before, ${ }^{7}$ Mulrunji turned into Dee Street where Senior Sergeant Chris Hurley and Indigenous Police Liaison Officer Lloyd Bengaroo were in the process of arresting a young man, Patrick Bramwell, for a public nuisance offence. Mulrunji knew Bengaroo, and as he walked past he said to Bengaroo something to the effect of "You're a black man like me, what are you doing this for?" - a kind of remark Bengaroo had received countless

3 Spivak Gayatri Chakravorty A Critique of Postcolonial Reason: Toward a History of the Vanishing Present Harvard University Press Cambridge 1991 p284.

4 Motha Stewart "Post-colonial law" in Cane Peter and Conaghan Joanne (eds) The New Oxford Companion to Law Oxford University Press Oxford 2008 p917.

5 Boe Lawyers Final Submission on behalf of the Palm Island Aboriginal Council 4 July 2006 available at http://www.boelawyers. com.au/documents/Palm\%Island/Coronial\%inquest/PIAC\%20-\%20Final\%20Submissions.04.07.06.pdf 3 (accessed 30 October 2008).

As above.

The medical evidence showed that Mulrunji had a high blood alcohol level at his time of death. His blood alcohol level did not contribute to the injuries that caused his death. See Clements C Inquest into the Death of Mulrunji Townsville: Office of the State Coroner 27 September 2006 pp 7-9, available at http://www.justice.qld.gov.au/courts/coroner/findings/ mulrunji270906.pdf (accessed 23 April 2008). 
times during his 25 years in the police force. ${ }^{8}$ Bengaroo responded by advising Mulrunji to continue walking down the street to avoid being arrested as well. Mulrunji followed this advice and continued walking. When Hurley got back into the police van, he asked Bengaroo what Mulrunji had said, and who he was - unlike many men in this over-policed ${ }^{9}$ community, Mulrunji had never been arrested on the island before and was thus unknown to Hurley, who had been stationed there for two years. ${ }^{10}$ Bengaroo informed Hurley of the interaction and told him Mulrunji's name. According to Hurley, Mulrunji then turned around and swore at the police officers. ${ }^{11}$ According to community witnesses, Mulrunji did not swear or turn around, but was singing "who let the dogs out?" - one of his favourite songs — as he continued walking down the street. ${ }^{12}$ At any rate, Hurley drove down to where Mulrunji had walked to, and arrested him. ${ }^{13}$ Mulrunji protested that he had done nothing wrong, and Hurley forced him into the police van. ${ }^{14}$ Less than an hour after the arrest, Mulrunji was dead. His body lay on the concrete floor of the police holding cell, having bled to death from a severe compressive force which cleaved his liver in two and ruptured his portal vein. He also had four broken ribs and a black eye. ${ }^{15}$

A couple of hours after his arrest, members of Mulrunji's family went to the police station to ask after him. Knowing that Mulrunji was dead, Hurley told the family that he was asleep and that they should come back at three o'clock. ${ }^{16}$ Hurley had already notified his police superiors in Townsville of Mulrunji's death, and two officers from Townsville, Detective Senior Sergeant Raymond Kitching and Detective Sergeant Darren Robsinson, were by that stage on their way over to the island. Both officers knew Hurley as a colleague, and it was common knowledge that Robinson and Hurley were close friends. ${ }^{17}$ Hurley picked up both men from the Palm Island airport that afternoon and entertained them as dinner guests at his home that evening. ${ }^{18}$ Over the course of the following week, Kitching and Robinson conducted interviews with Hurley, and with other witnesses to the events leading up to Mulrunji's death. It became clear that upon arriving at the station and opening the van to escort Mulrunji and Patrick Bramwell into the cells, Mulrunji had punched Hurley in the face, and the two men had then had "a tussle" as Hurley forced Mulrunji into the station. ${ }^{19}$ Hurley alleged that during the "tussle", he and Mulrunji had both tripped up the single step that leads into the station and fallen to the floor, being specific

Boe Lawyers above note 5 at $21-22$.

As above 57-63; Clements above note 7 at 32-33; For more information on the over-policing of indigenous communities in Australia see the Royal Commission into Aboriginal Deaths in Custody 1991 ("RCIADIC") chapter 13 available at http://www.austlii.edu.au/au/other/IndigLRes/rciadic/ (accessed 8 December 2008).

10 Clements above note 7 at $1-2$.

11 As above at 2.

2 Boe Lawyers above note 5 at 23; Waters Jeff Gone for a Song: A Death in Custody on Palm Island ABC Books Sydney 2008.

13 Clements above note 7 at 2 .

14 Boe Lawyers above note 5 at 22; evidence of Christopher Hurley in R $v$ Christopher James Hurley, Indictment No. $4 / 2007$ as reproduced in Hooper above note 1 at 229.

15 Clements above note 7 at $7-9$.

16 Boe Lawyers above note 5 at 48.

7 As above at 49; Clements above note 7 at 10 .

18 Clements above note 7 at 10-11.

19 Boe Lawyers above note 5 at 8 . 
that they had fallen beside and not on top of one another. ${ }^{20}$ Local man Roy Bramwell (Patrick's uncle), who was sitting inside the station when Hurley and Mulrunji came in from the van, gave a statement to Robinson that he had seen Hurley repeatedly punch Mulrunji when the two were in the hall of the police station, with Mulrunji on the ground and Hurley standing over him. ${ }^{21}$ This allegation of assault was not, however, included in the police information provided to the pathologist who was to perform the autopsy on Mulrunji's body. ${ }^{22}$ Lacking the allegation that there had been any kind of assault, this first autopsy attributed Mulrunji's death to an accidental fall. ${ }^{23}$

On 26 November, the autopsy results were publicly announced to the Palm Island community by then mayor Erykah Kyle. It had been a full seven days since Mulrunji died, and this announcement was the first information the community was to be given in relation to the death. Over a hundred people had gathered in the town square to hear the announcement. When Kyle made the announcement that Mulrunji's death had been caused by an accidental fall, the crowd was dissatisfied. Local men David Bulsey and then Lex Wotton stepped forward and took the microphone, expressing their anger at Mulrunji's untimely death at the hands of the police and demanding a full explanation. ${ }^{24}$ Soon, a small riot had begun, with members of the crowd throwing rocks and other make-shift projectiles at the police station, telling the police to leave the island and setting fire to the police station where Mulrunji had died, the nearby courthouse and the police barracks where Hurley had lived. ${ }^{25}$ The police took refuge in the local hospital, though none were seriously injured. ${ }^{26}$ In reaction to the riots, a senior Townsville police officer declared a state of emergency under the Public Safety Preservation Act 1986 (Qld) and by late afternoon, 80 police from a range of mainland cities had been deployed onto the island. They included the state's Special Emergency Response Team, who wore full battle armour and carried semiautomatic weapons. ${ }^{27}$ In total, 35 Palm Island residents were charged with offences relating to the riots. ${ }^{28}$ The majority of those charges were eventually withdrawn or dismissed, though significantly, Lex Wotton was recently sentenced to six years imprisonment for his involvement in the riots. ${ }^{29}$

Although the state of emergency response to the riot brought further trauma to the community, it also brought significant publicity to Palm Island. While some media reports focussed on the "lawlessness" of the indigenous rioters rather than on the death in custody that had provoked them, protest rallies around Australia demanded a full investigation into Mulrunji's

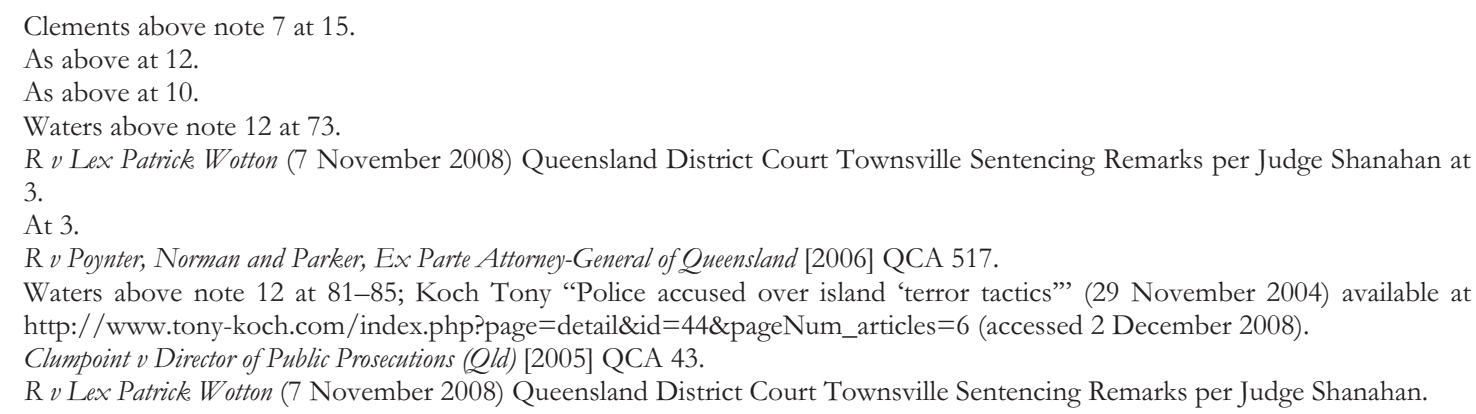


death and the apparent police cover-up that had followed it. ${ }^{30} \mathrm{~A}$ second autopsy was ordered, to be undertaken by a doctor from Melbourne. ${ }^{31}$ The upcoming coronial inquiry was guaranteed to be an event of significant public interest, and the prominent Burmese-born human rights lawyer Andrew Boe, from Brisbane, decided to act pro bono on behalf of the Palm Island Aboriginal Council. ${ }^{32}$ Boe met Chloe Hooper through mutual friends while he was visiting Melbourne shortly before the commencement of the inquiry in February 2005, and asked her to come to Palm Island and write an article about the proceedings, estimating that it would take around two weeks. ${ }^{33}$ As a young, white Australian woman novelist who had never heard of Palm Island before meeting Boe, Hooper was not the most obvious person to provide coverage of the inquiry. ${ }^{34}$ She ended up spending almost three years visiting and writing about Palm Island first publishing a series of articles in the current affairs magazine The Monthly, and then the full length "true crime"/non-fiction novel, The Tall Man: Death and Life on Palm Island.

My response to Hooper's book in this essay is primarily as a reader and a legal scholar, but I also spent a brief period working for Boe as a legal clerk, during which time I travelled to Palm Island for one of the coronial hearings. As such I have met (very briefly) most of the characters in Hooper's book, and have, like Hooper, had the experience of entering the Palm Island community as a non-indigenous young woman associated with Boe, who is well-liked and trusted there. ${ }^{35}$ Hooper wrote not only on the coronial inquest but on Hurley's manslaughter trial and acquittal that followed; on the far north-western "frontier" towns where Hurley had previously worked and where the Doomadgee family lived before they were removed to Palm Island; on the meetings of and personalities within the Queensland Police Union; and on the deaths of Mulrunji's teenage son, Eric, who hung himself a year and a half after his father died, and Patrick Bramwell, who hung himself half a year after Eric. Hooper was able to gain insights into life on Palm Island because she was placed in a significant position of trust by the Doomadgee family the Doomadgees trusted Boe, the non-white, pro bono lawyer for their community, and they trusted the writer he brought to cover the inquest. Questioned as to how she negotiated the ethics of writing about potentially vulnerable people while being outside any professional code of conduct or academic discipline, Hooper answered that she had her own code of conduct, which included a commitment to honesty, a desire to make the Palm Island situation known, and an ongoing debt to the Palm Island community and in particular to the Doomadgee family, who wanted their brother's story to be told. ${ }^{36}$ Mulrunji's great niece is now Hooper's god-daughter and she expresses a clear intention that her life will be linked with the Palm Island community for

30 "Arrests roll out continues on strife torn island" (2 December 2004) National Indigenous Times available at http://www.nit.com.au/BreakingNews/story.aspx?id=4131 (accessed 4 December 2008); Waters above note 12 at 123.

31 Waters above note 12 at 63; Tony Koch "Second autopsy for Palm Islander" (30 November 2004) available at http:/ / www.tony-koch.com/index.php?page=detail\&id=47\&pageNum_articles=6 (accessed 4 December 2008).

32 Boe Lawyers http://www.boelawyers.com.au/current\%20focus.html (accessed 5 December 2008).

33 Hooper above note 1 at 8 .

As above at 9 .

35 As I am mixed race and from regional Queensland though, I did not experience the same culture shock that Hooper did when she first arrived on Palm Island.

36 "Chloe Hooper in conversation with Sally Warhaft about the Tall Man" (July 2008) Slow TV available at http://www.themonthly.com.au/node/1100 (accessed 5 December 2008). 
a long time to come. ${ }^{37}$ Hooper's unconventional (or at least non-institutional) code of conduct is, I will argue in this essay, acutely self-reflexive - though never to the extent that the book becomes a story primarily about Hooper; ${ }^{38}$ and her method is uniquely effective in capturing the depth of the tragic injustice that occurred on Palm Island and of the role of law in that injustice. Hooper uses her position as a friend of the Palm Island community's lawyer and therefore of the Doomadgee family to put the people and the places involved in the Mulrunji case into nuanced context in a way that legal and academic texts cannot. Contrary to what might be expected of an author so close to one side of the story, she does not paint Hurley as a monstrously violent or racist man, but locates him within spaces of normalised violence and racism.

\subsection{The Legal Geography of Palm IsLand}

The Tall Man makes an important intervention into the commentary on Mulrunji's death in custody by mapping out and showing the contemporary relevance of decades of white laws and policies towards Palm Island. Hooper shows how the main subjects and places involved in Mulrunji's death are part of wider networks of social and legal relations. By outlining the laws and state policies that have helped produce current conditions on the island, and showing how those laws and state policies fit within the broader context of the colonial geography of Australia, she gives an account of the legal geography of Palm Island. The island was first gazetted as an indigenous "reserve" in 1914 under the Aboriginals Protection and Restriction of the Sale of Opium Act 1897 (Qld). While all reserves functioned as places of incarceration, Palm Island was specifically used as an open-air prison where indigenous people from other Queensland reserves were sent for punishment or if they were considered dangerous. ${ }^{39}$ Those considered dangerous included all "half-castes", who were regarded as not only a social problem, but also as a biological threat to the white race - the Queensland government saw Palm Island as a particularly attractive location to place indigenous people because it effectively isolated them from white people. ${ }^{40}$ Between 1918 and 1937 over half of Queensland's indigenous "removals" were to Palm Island. ${ }^{41}$ In all, indigenous individuals and groups from at least 57 different language groups were sent to Palm Island during its life as a penal colony. ${ }^{42}$ Families sent to the island were separated into the girls' and boys' dormitories and were only allowed to see each other with specific permission from a white superior. ${ }^{43}$ Separating and removing indigenous children from their families was official

37 As above.

38 I have argued elsewhere that Helen Garner's non-fiction novels are primarily books about Helen Garner, see Keenan Sarah "Review of Helen Garner's Joe Cinque's Consolation" (2006) Alternative Law Journal 31(1).

39 Royal Commission into Aboriginal Deaths in Custody 1991 Regional Report of Inquiry into Queensland Appendix 1(a): The Aboriginals in Colonial Society 1840-1897 available at http://www.austlii.edu.au/au/other/IndigLRes/rciadic/regional/ qld/ch5.html\#Heading22 (accessed 10 December 2008).

40 As above.

41 As above.

42 Palm Island: Future Directions Resource Officer Report State of Queensland (January 2006) p 27.

43 RCIADIC Regional Report of Inquiry into Queensland Appendix 1(a) above note 9. 
state policy across Australia until well into the 1970s, and indigenous children continue to be removed from their families today by state departments at a considerably higher rate than nonindigenous children. ${ }^{44}$

Hooper describes Palm Island during its early colonial history as "a kind of tropical gulag" 45 and "an island of stolen children". ${ }^{46}$ Moving on to the island's more recent history and its current living conditions, she calls it "a place where history is so close to the surface, so omnipresent, it seems to run parallel with daily life". ${ }^{47}$ The living presence of history on the island today is a theme that becomes increasingly strong through Hooper's descriptions of Palm Island over time and that resonates strongly with what geographer Doreen Massey might describe as the annihilation of time by space. In her 2006 book, For Space, Massey refutes arguments that "globalisation" has led to the annihilation of space by time because phenomena such as the internet, 24 hour financial trading and the collapse of spatial boundaries for capitalist forces like McDonalds and Sony have cumulatively led to a new irrelevance of space. ${ }^{48}$ These arguments do not hold up because space, as Massey argues, is more than distance - space is multiplicity, it is the "simultaneity of stories so far", and it is still highly relevant, particularly to places outside the western capitalist areas that drive "globalisation". 49 Palm Island is such a place — located physically and culturally outside the relative prosperity of what is popularly understood as the first world, predominantly white nation-state of Australia, globalisation has certainly not made space irrelevant there. Indeed, as will be explored below, it can be argued that space is far more relevant on Palm Island than time because its colonial geography has been largely unchanged by history.

In 1986 the Queensland government relinquished direct control over Palm Island pursuant to the Community Services (Aborigines) Act 1984 (Qld), which granted land title to the newly formed community council under a "deed of grant in trust" ("DOGIT"). ${ }^{50}$ Under a DOGIT — a species of land title created specifically for the self-administration of former missions and reserves - the land must be used for the benefit of the community, meaning that private ownership of land is unlawful. ${ }^{51}$ While these legal moves were positive in terms of indigenous self-government, they were accompanied by a swift withdrawal of government infrastructure from the island..$^{52}$ The physical isolation of Palm Island combined with the cumbersome legal intricacies of the island's DOGIT land tenure scheme have made it very difficult for the island to attract any kind of outside investment in the community. ${ }^{53}$ As the residents on Palm Island are either former reserve inmates who were given little or no remuneration for their work, or the children of those inmates,

44 Bringing Them Home: Report of the National Inquiry into the Separation of Aboriginal and Torres Strait Islander Children from Their Families 1997 available at http://www.austlii.edu.au/au/other/IndigLRes/stolen/index.html (accessed 10 December 2008).

45 Hooper above note 1 at 11.

$46 \quad$ As above at 57.

As above at 10 .

Massey Doreen For Space Sage London 2006 pp 81-91.

As above.

Now governed by chapter 3 of the Land Act 1994 (Qld).

As above s35.

Waters above note 12 at 41 .

53 Boe Andrew "Palm Island — Something is very wrong" Australian National University Public Lecture Series 2005 (28 September 2005) p 8 . 
there is also no economic base upon which to begin local industry. As such, Palm Island today is a place of severe poverty. Houses are severely overcrowded (averaging 17 people per house) ${ }^{54}$ and run-down, ${ }^{55}$ and unemployment is over $90 \% .^{56}$ Suicide and domestic violence rates are disproportionately high. ${ }^{57}$ The Tall Man does not set out all these statistics, but makes clear through its detailed narrative the ongoing relevance of the island's colonial history and geography to its present conditions.

As well as being a creature of specific state laws and policies, Palm Island is also a product of what is described in The Tall Man as a significant north-south axis of Australian race relations. Hooper's narrative is mainly set on Palm Island and Townsville - both places of the far north Queensland coast, and both culturally distinct, in many ways, from Hooper's hometown of Melbourne at the opposite end of the country. The cultural differences are demonstrated primarily through the small details in Hooper's narrative. For example, Hooper writes of her interaction with her taxi driver upon arriving at Townsville airport - he claimed he could always pick those who had arrived from "down south" - "How?" I asked, "Because they're fuckwits", he answered. ${ }^{58}$ As well as Palm Island, Hooper travels to other remote far north Queensland towns including Doomadgee, the tiny ex-mission town where Mulrunji's father lived before being sent to Palm Island, and Burketown, another small "frontier" town where Hurley had worked for four years before transferring to Palm Island. Hooper finds the same racial tension and atmosphere of colonial violence in each of these far north Queensland towns, a tension and atmosphere that is foreign to her as a white woman from Melbourne. While driving through far north Queensland she observes the road signs to Spear Creek, Rifle Creek, Double Barrel Creek and Revolver Creek, the violent place names being another example of the patent living presence of colonial history in north Queensland. ${ }^{59}$ A little further south in Brisbane, Hooper continues to find evidence of the north-south divide at a Queensland Police Union meeting called in support of Hurley, describing the exuberant self-righteousness of the union as "real-life, uber Australia up against insipid, politically correct, bullshit Australia. It was North against South". ${ }^{60}$

In this description of Australia's north-south divide, Hooper positions herself from the outset as a Melbourner - a white, educated woman from the state capital located on the southernmost coast of its mainland and generally regarded as the nation's elite cultural heart. Indeed Hooper creates the north-south divide for her readers mainly by describing the ways in which she finds her bourgeois Melbourne sensibilities out of place in far north Queensland. When she first arrives on Palm Island, Hooper feels "incandescently white" 61 - she is in a place where her whiteness does not give her the usual unspoken advantage of slipping quietly into her surrounds, without having to think about race. Feeling incandescently white is a moment of self-

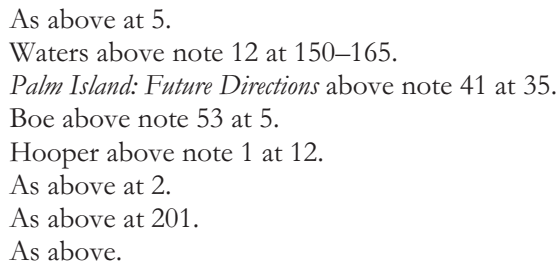


Australian Legal Geography and the SEARCh For Postcolonial SpaCe in Chloe Hooper's

THE TALL MAN: DEATH AND LIFE ON PALM ISLAND

realisation for Hooper - her travels to the north lead her to realise her own whiteness and the whiteness of the Australian legal system. "Whiteness" is a fluid and relative term, having different meanings in different contexts. ${ }^{62}$ Ruth Frankenburg defines whiteness as constituted by three linked dimensions: "a location of structural advantage"; a white "standpoint", that is, a white worldview or perspective of self, society and other; and "a set of cultural practices that are usually unmarked and unnamed". ${ }^{63}$ As Simeon Moran has argued, these three dimensions of whiteness may be loosely categorized as the domains of society, subjectivity and culture, all of which are interdependent on each other. ${ }^{64}$ The inclusion of subjectivity in these three interdependent domains means that individual subjects, through their ordinary daily lives, participate (often unknowingly) in the reproduction of white privilege and non-white disadvantage. ${ }^{65}$ As a privileged white woman from Melbourne, Hooper is implicated in the racial disadvantage she discovers on her travels north in ways that she does not fully explore. By describing herself as a southerner and then emphasizing that race relations are worse in the north than the south, it could be argued that Hooper is unfairly distancing herself from racism against indigenous Australians, which occurs with deadly violence in the southern states too. ${ }^{66}$ On the other hand though, Hooper's lack of focus on her own subject position means that she avoids attempting to transcend her whiteness and her privilege by making a point of declaring them. As Sara Ahmed has powerfully shown, declaring one's own whiteness in a white-dominated space tends to create the fantasy that the declarer has thereby transcended her whiteness, when such fantasy is itself afforded by white privilege and can operate to reproduce it. ${ }^{67}$ Hooper's narrative never pretends to be an innocent or "objective" commentary removed from the events she writes about, but her focus is on the broader spaces in which she is situated rather than on her own subject position.

By positioning Palm Island within an extensive web of colonial laws, policies, relations and understandings, Hooper makes it clear that it is a place that can only be meaningfully understood in the context of its position within the wider space of Australian legal geography. Her intimate narrative of Palm Island today set against her well-researched account of the island's colonial history shows that Palm Island is a place constructed by decades of colonial relations, processes, experiences and understandings. Hooper's account reflects an anti-essentialist understanding of place - place as constructed and contingent rather than pre-existing and fixed. The Tall Man makes it clear that Palm Island has been embedded in and defined by networks of Australian race relations and politics ever since the beginning of its colonial history as an island prison. The persistent conditions of poverty and despair on Palm Island are not due to some inherent fault of the island or its community but are instead due to the fact that the networks of racist relations,

62 see for example Ahmed Sara 'A phenomenology of whiteness' (2007) 8(2) Feminist Theory 149 and Fine M, Powell LC, Weis L, L Mun Wong (eds) Off-White: Readings on Race, Power and Society Routledge New York 1997.

63 Frankenburg Ruth The Social Construction of Whiteness: White Women, Race Matters Routledge London 1993 p 1.

64 Moran Simeon 'White lives in focus: connecting social praxis, subjectivity and privilege' (2004) 3(2) borderlands e-journal.

65 As above.

66 Although cleared by the coroner, many believed the New South Wales police to be responsible for the 2004 death of indigenous boy Thomas TJ Hickey in Redfern. Similarly, although cleared by the courts, Victoria police were criticised for leaving indigenous man Paul Carter on a highway while he was highly distressed in 2006. Carter was killed when struck by a truck after the police left him.

67 Ahmed Sara 'Declarations of Whiteness: The Non-Performativity of Anti-Racism' (2004) 3(2) borderlands e-journal. 
processes, experiences and understandings that constituted the space of colonial Australia have not significantly shifted, despite certain legislative reforms. Thus although Palm Island is now subject to a DOGIT, a type of indigenous land right created at a time when the movement for indigenous civil and land rights had had a number of recent successes, ${ }^{68}$ and when Australian law appeared to be making attempts to break from its colonial past, ${ }^{69}$ it has not brought significant gains to the community. For Palm Island to move into a space of postcoloniality will require far more fundamental and wide-ranging shifts than the granting of limited civil and land rights to indigenous Australians. This anti-essentialist approach to place and space resonates with geographer Doreen Massey's understanding of place as "constructed out of particular interactions and articulations of social relations, processes, experiences and understandings, where a large proportion of those relations, experiences and understandings are constructed on a far larger scale than what we happen to define for that moment as the place itself". ${ }^{70}$ So instead of thinking of places as areas with boundaries around, Massey imagines them as articulated moments in networks of social relations and understandings..$^{71}$ Within those networks, different individuals and different social groups are placed in distinctly different positions of power. ${ }^{72}$ According to this understanding, place is a process rather than an artefact, and correspondingly, space is dynamic and heterogenous, rather than static and fixed in meaning. ${ }^{73}$ Like Massey, Hooper insists on the existence and importance of the spatialised power relations and politics within which places are located. ${ }^{74}$

Importantly, the spatialised power relations within which Hooper places Palm Island include the continuing legacy of the original violence of colonisation. That original violence is inescapably encoded in Palm Island's "position" - not just its physical position as a small isolated landmass off the coast of far north Queensland, but its economic position as a place of poverty, its cultural position as a place of many different indigenous groups forced to live together on land far removed from their ancestral homes, and its social position as an island no white person would dream of visiting unless required to for work. White people who do work on Palm Island are housed in separate, higher quality accommodation (the police on the island live in barracks surrounded by high fences and barbed wire), creating a space in which the original colonial violence of dispossession is part of everyday life. Hooper's analysis of Palm Island in terms of spatial formations of violence resonates with the work of critical geographers Nick Blomley and Alan Feldman, who have both argued that particular spaces can encode and perform

68 For example the passage of the 1967 Constitutional amendment to recognise and make federal laws for Indigenous people; the establishment of the permanent Aboriginal Tent Embassy in Canberra in 1972; the passage of the Indigenous Land Rights Northern Territory) Act 1976 (Cth); and the prominent indigenous protests at the Brisbane Commonwealth Games in 1982.

69 The Australia Act 1986 (Cth) and the corresponding Australia Act 1986 (UK) made the Australian High Court the ultimate court of appeal for Australian courts, replacing the House of Lords, and ended the British government's right to make laws for Australian states.

70 Massey Doreen 'Power-geometry and a progressive sense of place' in Curtis Barry , Bird Jon, Putnam Tim ,Robertson George and Tickner Lisa (ed) Mapping the Futures: Local Cultures, Global Change Routledge London and New York $1993,66$.

71 As above.

72 As above, 61.

73 Michael Keith and Steve Pile 'Introduction Part 2: The Place of Politics' in Keith Michael and Pile Steve (ed) Place and the Politics of Identity Routledge London 1996.

74 Massey above note 48. 
Australian Legal Geography and the SEARCh For Postcolonial SpaCe in Chloe Hooper's

THE TALL MAN: DEATH AND LIFE ON PALM ISLAND

state violence. Blomley - whose work is generally regarded as the foundation of "legal geography" - thinks about space as something which is produced by social performances and which also disciplines the social performances that occur within it. ${ }^{75} \mathrm{He}$ argues that border walls, domestic family homes, and wherever those engaged in criminalized activities such as sex work and non-prescriptive drug trading are forced to do business, are examples of spaces where the law tolerates violence to the extent that material landscapes actually encode and perform state violence. ${ }^{76}$ Similarly, Alan Feldman has argued in a specifically "post"-colonial setting, that spatial formations of violence continue to exist in Northern Ireland. The originating violence of colonisation is remote in time but also permanent, in that it leaves behind spatial formations that guarantee ongoing repetitions of itself - both in terms of the memory it institutes and the actual antagonisms between groups that it systematically provokes. ${ }^{.7}$ Those who live in the space are thus caught in a permanent memorialisation and in actual repetitions of the original violence. This is not to say that such spaces are impossibly fixed in violent meaning, but that in order for the space to shift in meaning and be performed differently, the significance of the original violence cannot be ignored.

As Hooper's descriptions of her visits to other remote communities in far north Queensland show, the spatial formation of violence experienced by Palm Island is not unique many remote indigenous communities in Australia are equally physically isolated and culturally dispossessed - an isolation and dispossession stemming from the same original act of colonial violence. While the details of the individual removals and the current schemes of limited land title may differ, the experiences of remote indigenous communities are very similar - community members who remain face extremely limited prospects of ever moving out of poverty, they struggle to retain the remnants of their culture that have survived two centuries of white Australia, and they face everyday the despair and desolation left by the originating act. Their alternative is to leave their land and "assimilate" into a foreign white capitalist culture built on indigenous genocide and dependent on permanent indigenous dispossession, thereby making it even more probable that their land and their own culture will indeed die out completely as assumed by the first settlers. ${ }^{78}$ This situation, as Irene Watson has argued, is one in which the idea of Indigenous independence, difference and diversity is hunted out - Indigenous communities are told to take responsibility for essential services while their socio-economic and political position remains unchanged, remote "unsettled" spaces become increasingly difficult to live in, but those who move into the "settled spaces" of white towns and cities run the risk of becoming so good at taking responsibility that they become absorbed into the white oneness of Australia. ${ }^{79}$ The unsettled spaces of remote indigenous communities are not just remnants of the original act

75 Blomley Nicholas 'Law, Property, and the Geography of Violence: The Frontier, the Survey and the Grid' (2003) 93(1) Annals of the Association of American Geographers 121.

76 As above at 123 and 132

77 Feldman Allen Formations of Violence: The Narratives of the Body and Political Terror in Northern Ireland University of Chicago Press London 1991.

78 This is not to assert that remote indigenous communities are defined exclusively by colonial violence - they still operate as important spaces of indigenous culture, but the extreme difficulties faced by these communities stem from that violence.

79 Watson Irene 'Illusionists and Hunters: Being Aboriginal in this Occupied Space' (2005) 22 Australian Feminist Law Journal 15. 
of colonial violence, but rather are permanent spatial formations of it - the common position of remote indigenous communities is one in which the violence of the founding of white Australia is an inescapable part of everyday life. The legal geography set out in The Tall Man makes it clear that Palm Island is part of that unsettled space. Palm Island today is an articulated moment in the wider space of the ongoing Australian colonial project - a place that both memorialises Australia's original colonial violence and ensures ongoing re-performances of it.

\subsection{WHITE SPACES AND GEOGRAPHIES OF IRRESPONSIBILITY}

By positioning Palm Island within the context of its legal geography, The Tall Man avoids a simplistic narrative of the story with Hurley as a bad man with sole responsibility for Mulrunji's death. Instead, Hurley is part of a bigger picture in The Tall Man - he is a feature in the landscape of Australian colonial geography. By looking at the whole landscape, Hooper casts the net of responsibility for Mulrunji's death far beyond the individuals directly involved in it - the net is cast over the networks of relations, experiences, processes and understandings that led Hurley and Mulrunji to be in their respective positions on the morning Mulrunji died. Those networks include all comfortable, non-indigenous Australians whose lives depend on the maintenance of Australia's colonial geography, and on whose behalf Hurley serves. In casting this extensive net of responsibility, Hooper's approach again has strong resonances with a critical geography approach to space, place and their interconnectedness. Consistent with her understanding of place as extraverted rather than bounded, and of space as active and constantly under construction, Massey calls for a politics of connectivity based on geographies of responsibility. ${ }^{80}$ This politics would mean invoking responsibilities to strangers well outside the picket fences, apartment blocks, city walls or state borders that tend to act as restrictive boundaries on who "we" have responsibility to in capitalist societies like Australia. ${ }^{81}$ Massey's politics of connectivity would instead mean recognising the multiple networks of understandings, relations, processes and experiences that intertwine to form place, and drawing lines of responsibility along the multiple trajectories of those networks that extend out from it. Because those networks are not static but always under construction, geographies of responsibility require constant negotiation to find particular answers to particular questions of place and space. ${ }^{82}$ There are no universal rules, but what is constant is everyone's interconnectedness - we have responsibilities to people and places far away because we are connected to and dependent on them. Massey's understanding of space and place, like Hooper's analysis of Mulrunji's death in custody, casts a wide net of responsibility, thereby complicating the story and raising troubling questions about the geographies of irresponsibility that appear to be entrenched in "postcolonial" Australia.

\footnotetext{
82 Massey above note 48.

Massey Doreen 'Geographies of Responsibility' (2004) 86B(1) Geografiska Annaler 5.
} 
Australian Legal Geography and the SEARCh For Postcolonial SpaCe in Chloe Hooper's

THE TALL MAN: DEATH AND LIFE ON PALM ISLAND

Although Hooper's requests to interview Hurley were repeatedly ignored, ${ }^{83}$ she nonetheless offers a rich and nuanced profile of him to readers, based mainly on speaking to his friends and acquaintances. Hooper presents Hurley as having a "most ordinary" upbringing — he attended a Catholic boys' school in a working-class Brisbane suburb, his father was president of the Parents and Friends Association, he played rugby at school, and after working at a bank for a year postgraduation, he joined the Queensland police force. ${ }^{84}$ This is a "most ordinary" upbringing for non-indigenous Australians, as indigenous Australians are considerably less likely to attend a private school, to have a childhood free of chronic disease, and to find full-time employment. Hooper recounts how at 21 , Hurley was transferred to the remote, largely black community of Thursday Island in the Torres Strait, where he spent two years. It was on Thursday Island, Hooper's research shows, that Hurley had realised he was racist, and decided to change. ${ }^{85} \mathrm{He}$ continued working in remote black communities in part to confront his own racism but also because he could climb the police hierarchy much more quickly than if he were working anywhere else. In the years following his placement on Thursday Island Hurley worked in a number of Aboriginal and Torres Strait Islander communities in Queensland — "frontier towns" of the deep north where he was the higher ranking of the two police in town. ${ }^{86}$ Hooper describes how Hurley socialised with locals at the pub, played sport with indigenous children, and developed his own style of policing that tended not to comply with the letter of the law. ${ }^{87}$

Hooper's profile of Hurley is of a white man from an ordinary upbringing whose work took him into extraordinary places. The Queensland police establishment argued on numerous occasions that Hurley and all police working in remote indigenous communities are doing it for the rest of "us" 88 - they are out there on our behalf, enforcing our laws, doing our dirty work. And this argument has great weight if the collective "we" being assumed in these statements is white Australia. ${ }^{89}$ For as long as "ordinary", white men like Hurley are willing to don a police uniform and venture out into frontier towns that are now sites of indigenous poverty, despair and "dysfunction", the rest of us can forget that colonial dispossession is an ongoing process that did not stop with Mabo, ${ }^{90}$ with anti-discrimination law or even with the long-awaited apology. While these liberal gestures towards "equality" do represent a movement away from the blatant racism of Australia's colonial foundations, they also reiterate, as Stewart Motha has argued, that the law of the coloniser is the only valid normative system. ${ }^{91}$ Indigenous "rights" are recognised only within the white legal system and on terms defined by it, thereby reinforcing the hegemony of the

83 Hooper above note 1 at 235.

84 As above at 116.

85 As above at 21.

86 As above at 132 .

87 As above at 133-143.

88 see for example the statement of Police Minister Judy Spence on “The Law Report” (11 November 2008) ABC Radio National available at http://www.abc.net.au/rn/lawreport/stories/2008/2416076.htm (accessed 12 November 2008).

89 I use the term "white Australia" in this context to include all non-indigenous Australians who benefit from the ongoing displacement of indigenous Australians. This includes non-white non-indigenous Australians (in which I include myself), but I use the term white because of its political potency in the context of Australian indigenous issues and because the dominant culture and political system in Australia are still white despite the rhetoric of multiculturalism.

$90 \quad$ Mabo v Queensland (No 2) (1989) 166 CLR 186.

91 Motha Stewart 'The Failure of "Postcolonial" Sovereignty in Australia' (2005) 22 Australian Feminist Law Journal 107. 
white legal system, the subordination of Indigenous laws and the un-thinkability of it being any other way. In recognising and "granting" indigenous rights, the colonial state redefines itself and its legal system as "postcolonial" - as having departed from its colonial antecedents and moved to something else. But the legal system that "grants" indigenous land rights and prohibits discrimination on the basis of race $^{92}$ is the same legal system that incarcerates indigenous Australians at over 15 times the rate of non-indigenous Australians, ${ }^{93}$ undermines and belittles indigenous ways of knowing, ${ }^{94}$ and refuses to acknowledge that its foundations lie in violent conquest. ${ }^{95}$ The Australian government boasts about (some) families in remote communities feeling more safe and secure with increased police presence, but fails to recognise the systemic reason those communities are unsafe and insecure in the first place. ${ }^{96}$ As Andrea Smith has argued in regard to hate crime law, when a state founded on genocide purports to protect racial minorities, it reproduces white supremacy by masking the racism of the state itself. ${ }^{97}$ In regard to policing in remote communities, the law purports to bring protection and equality to indigenous Australians through men like Hurley, but in doing so it reproduces the supremacy of white Australia — a supremacy that most Australians in non-remote areas take for granted.

Rather than accepting or allocating responsibility for colossal wrongs of the past and ongoing wrongs of the present, law tends more to make responsibility disappear, in the case of Mulrunji's death in custody and more broadly. Scott Veitch argues that law actually organises and legitimates irresponsibility, citing as a key example the way in which Australian common law, on the grounds of equality, freedom and formal justice, has legitimated the ongoing dispossession of indigenous people and the effective disavowal of Australia's racially violent past. ${ }^{98}$ Our "postcolonial" Australian legal system still depends on the continued dispossession of indigenous people from their land and their culture - because if indigenous claims to ownership and sovereignty were heeded, then where would non-indigenous Australians go? Who would we be? What would a non-colonial system look like in this now well-settled state? The idea of living in an Australia where the white system was anything other than present, ongoing and supreme has never been seriously entertained by those who control and depend on it. Instead, non-indigenous Australians whose lifestyles depend on ongoing indigenous dispossession, take comfort in the "postcolonial" legal reforms and get on with our lives, while men like Hurley move out of sight and into the desert frontiers to deal with the consequences of the ongoing dispossession.

In certain circumstances. Notably, the Racial Discrimination Act 1975 (Cth) was excluded from the Northern Territory Emergency Response Act 2007 (Cth): s132(2).

93 "A statistical overview of Aboriginal and Torres Strait Islander People in Australia" (August 2006) Australian Human Rights Commission available at http://www.hreoc.gov.au/Social_Justice/statistics/index.html\#toc9 (accessed December 14 2008).

94 See for example the Hindmarsh Island Bridge affair, critiqued in Bell Diane Ngarrindjeri Wurruwarrin: a world that is, was, and will be Spinifex Press Melbourne 1998.

95 Watson above note 79.

96 Macklin Jenny MP, "Australian Government Response to the NTER Review" (23 October 2008) available at http://www.jennymacklin.fahcsia.gov.au/internet/jennymacklin.nsf/content/nter_measure_23oct08.htm (accessed 12 June 2009).

97 Smith Andrea 'Unmasking the State: Racial/Gender Terror and Hate Crimes' (2007) 26 Australian Feminist Law Journal 47.

98 Veitch Scott Law and Irresponsibility: On the Legitimation of Human Suffering Routledge Cavendish Abingdon 2007 pp $99-114$. 
Australian Legal Geography and the SEARCh For Postcolonial SpaCe in Chloe Hooper's

THE TALL MAN: DEATH AND LIFE ON PALM ISLAND

The Tall Man is rich with lived examples of the failure of Australian law to operate in a way that is postcolonial. After the initial investigation into Mulrunji's death was taken over by the Crime and Misconduct Commission; after the riots had been heavily suppressed, and after a false start in which the Queensland coroner was forced to stand down because of the appearance of bias, the coronial inquiry into Mulrunji's death in custody finally got underway. Police witnesses gave evidence in the Townsville courthouse, while in separate hearings community witnesses gave evidence in the indoor basketball court of the newly opened Palm Island Police Youth Club Centre. In attendance at the initial hearings on Palm Island, Hooper recounts the painful interactions between community witnesses and the lawyers questioning them. The community witnesses were petrified at the sea of suited white bodies taking turn to interrogate them in fast, often complex English over seemingly irrelevant details. ${ }^{99}$ Verna Snyder had been walking with Mulrunji in Dee Street the morning he was killed. She was called to give evidence; "emaciated, bare-foot, shaking, apparently a severe alcoholic" Verna breaks down mid-testimony, distraught, overwhelmed and unable to communicate with the lawyer questioning her; while she sits weeping, a stray horse puts its head through the door, the breeze disturbs the coroner's papers, and Hooper feels "sick... the whole thing was hopeless". ${ }^{100}$ As she continued to watch the community witnesses struggle to tell the court what happened the day Mulrunji was killed, Hooper could feel the story "slipping away". ${ }^{101}$ Her verbatim accounts of the lawyer-witness interactions together with her observations of the spatial disjuncture between Palm Island and the legal system that had come to visit it make obvious the whiteness of the law. The whiteness of the coronial inquiry becomes evident when it is moved to Palm Island — its language, its methods, its goals, the bodies in charge of it and the constructed physical space it required to proceed were all from a white standpoint, systemically privileging a white social and cultural understanding of the world in a way that appears unremarkable in the landscape of most mainland towns and cities but that appears distinctly out of place on the island. Taking the stand at Hurley's criminal trial in the Townsville Supreme Court building over 12 months later, where there is air-conditioning, carpet and a wooden carving of a British lion hanging above a judge wearing red and white robes, Verna Snyder thought she was the one on trial, shaking in fear when asked by Hurley's tall white lawyer how much Mulrunji had had to drink — "No. I don't drink. Never!" ${ }^{102}$ "The law pretended it could pin [Hurley] down, cut him to size," 103 Hooper writes, but her exposition of this palpably white legal system makes predictable its ultimate failure to do anything but pretend.

The whiteness of law also becomes evident through Hooper's descriptions of Hurley's manslaughter trial in Townsville, in which Mulrunji was understood as belonging to a space of violence and indigeneity in contrast to Hurley, who was assumed to belong to the "common sense" space of white Australia. In her discussion of the trial of two young white men who killed an indigenous prostitute, Pamela George, in Canada in 1995, Sherene Razack argues that the enormity of what was done to George and her family remained largely unacknowledged because

99 Hooper above note 1 at 93-98.

100 As above at 94.

101 As above at 100 .

102 As above at 215.

103 As above at 237. 
George was considered to belong to a space of prostitution and indigeneity, in which violence regularly occurs, while her killers were presumed to be far removed from that zone. ${ }^{104} \mathrm{~A}$ similar analysis can be applied to Hurley's manslaughter trial. The jury were told by the defence lawyer at the very start of the trial to not throw their "commonsense" out the window, "You came here with your common sense and experience of the world, and we would say to you, 'please use it when you listen to the evidence"'. ${ }^{105}$ Hooper goes on to consider what might constitute an all white Townsville jury's experience of the world, discussing in some detail the results of a 2006 survey of Townsville residents about their perceptions of Aboriginal and Torres Strait Islander people. ${ }^{106}$ Less than $15 \%$ of the responses were deemed positive, and when asked specifically about Palm Islanders, responses included "leave them on the island" and "glad they are over there". ${ }^{107}$ The appeals to the jury to retain their "commonsense" and "experience of the world" were appeals to retain the common understanding of Palm Island as a place of indigeneity and violence, a place to be kept separate from the civilized mainland, and a place that required heavyhanded policing. The Palm Island community witnesses, whose black bodies and old, mismatched clothes already marked them as out of place in the courtroom, were aggressively questioned as to how much they had had to drink, and whether they had been involved in violence, the night before Mulrunji was killed, feeding directly into stereotypes about indigenous people. ${ }^{108}$ By contrast, when Hurley's lawyer called upon Hurley himself as a surprise witness, he smugly invites the jury to "assess him," 109 and in closing asks "isn't he precisely the sort of police officer you'd like to have as your local copper?", reminding the jurors that "when Senior Sergeant Hurley went out that morning to respond to the request, he did it on our behalf". ${ }^{110}$ This language of the defence lawyers drilled home the spatial separation between the Townsville jurors - the collective "us" on whose behalf Hurley served, and the Palm Island community - "them", who drink excessively and live in violence over there. Throughout the trial, Mulrunji was understood as belonging to Palm Island and to its violence, alcoholism and indigeneity, whereas Hurley was understood as a white visitor in that space, sent their "on our behalf" to contain the natives. Against this racialised topology, the enormity of what was done to Mulrunji and his family remained largely unacknowledged.

Although in the trial Hurley was understood as belonging to a space of whiteness, law and respectability and Mulrunji to a space of violence, alcoholism and indigeneity, the history and politics behind those racialised spaces were explicitly absent. The Tall Man shows how there was no scope in the courtroom to discuss, let alone interrogate, why Palm Island operates as a racially segregated ghetto or why white policemen in remote indigenous communities tend to become laws unto themselves. Hooper quotes Hurley's lawyer in his summing up, urging the jury that

104 Razack Sherene H. 'Gendered Racial Violence and Spatialized Justice: The Murder of Pamela George' in Razack Sherene H. (ed) Race, Space and the Law: Unmapping a White Settler Society Between the Lines, Toronto 2002 p 121 at 125.

105 Transcript to Indictment No. 4/2007 Rv Christopher James Hurley (Queensland Supreme Court at Townsville) as reproduced in Hooper above note 1 at 211 .

106 Hooper above note 1 at 212.

107 As above.

108 Transcript reproduced in Hooper as above at 214-216.

109 As above at 228

110 As above at 249 . 
Australian Legal Geography and the SEARCh For Postcolonial SpaCe in Chloe Hooper's

THE TALL MAN: DEATH AND LIFE ON PALM ISLAND

"people who would discuss this case in racial terms have got the wrong attitude." 111 Drawing again on Razack's discussion of the murder trial that followed the killing of Pamela George, she argued that history was precisely what was absent in the trial, and that "as abstractions, neither side could be seen in the colonial project in which each was embedded". ${ }^{112}$ The Tall Man provides that context — albeit after the fact and outside a formal legal setting, Hooper's analysis places Hurley and Mulrunji firmly within the wider space of Australia's ongoing colonial project.

Within that space, everything was within reach for Hurley and out of reach for Mulrunji and the Palm Islanders who witnessed his arrest and killing. Sara Ahmed describes colonialism as a process that makes the world white, putting certain objects within reach for white bodies and out of reach for non-white bodies. ${ }^{113}$ Whiteness, she argues, is "an orientation that puts certain things within reach", where things include physical objects, styles, capacities, aspirations, techniques and habits. ${ }^{114}$ White bodies feel comfortable in white spaces because the spaces hold those bodies up, allowing them to extend their reach. ${ }^{115}$ Within the courtroom, a thoroughly white space, everything was within reach for Hurley - a white man dressed in his best suit, he spoke in clear English, understanding what he needed to do and being able to communicate with - to reach out to - the jury. And what was within reach for Hurley extended far beyond the courtroom. Also within his reach were the two investigating officers sent to gather the crucial initial evidence - both of them were his friends, while for Palm Island witnesses they were intimidating figures of authority. The extensive financial resources of the Queensland Police Union put his choice of legal representation within reach, while the Palm Island community relied on Legal Aid and pro bono representation. While Hurley continued on full pay and enjoyed the vociferous support of his union during the lead up to his trial, the Palm Island community continued to struggle in poverty and despair, losing two young men through suicide, Mulrunji's only child Eric, and potential witness Patrick Bramwell. In light of the stark differences between what was within reach for Hurley's side and what was within reach for Mulrunji's by the time the case came to trial, it is unsurprising that despite Hurley eventually admitting that he must have inadvertently killed Mulrunji, ${ }^{116}$ he was fully acquitted by the jury on 20 June 2007. Hurley was not responsible for Mulrunji's untimely death - under the law, no one was. The law not only failed to allocate responsibility for Mulrunji's death - through its protracted inquest and trial, it organised and legitimated irresponsibility around Mulrunji's death.

Hurley's not guilty verdict was handed down the day before the Howard government announced that as a response to the "Little Children are Sacred" report released six days earlier, it would be using federal powers to make an "emergency" intervention into remote indigenous communities in the Northern Territory, where it had been "revealed" that large numbers of

111 As above at 254.

112 Hooper above note 1 at 126.

113 Ahmed Sara 'A phenomenology of whiteness' (2007) 8(2) Feminist Theory 149.

114 As above at 154.

115 As above at 158.

116 Clements above note 7 at 25; transcript to Indictment No. 4/2007 R v Christopher James Hurley (Queensland Supreme Court at Townsville) as reproduced in Hooper above note 1 at 231-232. 
indigenous children were suffering sexual abuse at home. ${ }^{117}$ The intervention, which is still in place today, includes sending military forces and federal police into remote communities, and has led to increased numbers of indigenous people moving from those communities into "mainstream" towns. ${ }^{118}$ While the precise timing of Hurley's acquittal and the federal government's emergency intervention was in certain respects coincidental, each must be read within the immediate context of the other, as together they epitomise white law's treatment of indigenous Australians. While Hurley's trial affirmed the relation of irresponsibility between police and their indigenous prisoners, the intervention sent more police into remote indigenous communities, and white Australia continued living their lives, catching the occasional glimpse of indigenous despair on the news. Hooper reflects on the report and the trial:

The war between police and Aboriginal Australians is a false battleground. The spotlight on Hurley and Doomadgee locked in a death struggle ignored the great horror taking place offstage. The Little Children Are Sacred report described Australia after the Fall. It seemed to me that concentrating on a white man killing a black man took the nation back to its original sin, as if expurgation of this would stem the rivers of grog and the tides of violence drowning life in these communities. If we could absolve ourselves of this first sin we might be able to pretend that the later ones — the ones now killing a generation — happened in a realm beyond our reach and responsibility. ${ }^{119}$

After Hurley was acquitted, Hooper encountered significant popular support for him in Townsville, and she suggests that Hurley had "not so much been acquitted as forgiven. And in forgiving him, people forgave themselves." 120 The Tall Man casts a wide net of responsibility over the whitened space of "postcolonial" Australia — a net that stretches far beyond Palm Island and the Queensland police force, but it finds that instead of allocating that responsibility, white law entrenches relations of irresponsibility, maintaining a persistently white, colonial space.

\subsection{SAVING WOMEN AND CHILDREN}

Although Hurley's acquittal and the Northern Territory intervention occurred within days of each other, little has been made of the link between the two. The professed purpose of the intervention was (and still is) to save indigenous women and children from indigenous men. That purpose was not articulated as a justification for Hurley's acquittal, but it was the implicit framework for Hurley's actions - from his presence in Dee Street the morning he arrested

117 The full title of the "Little Children are Sacred Report" is the Northern Territory Government Inquiry into the Protection of Aboriginal Children from Sexual Abuse and is available at http://www.nt.gov.au/dcm/inquirysaac/ pdf/bipacsa_final_report.pdf. The Northern Territory Emergency Response Act 2007 (Cth) came into force on 18 August 2007.

118 "Taskforce heads reflect on intervention anniversary" (21 June 2008) ABC News available at http://www.abc.net.au/ news/stories/2008/06/21/2281620.htm (accessed December 16, 2008); "Intervention 'a smokescreen for land grab" (25 May 2008) ABC News available at http://www.abc.net.au/news/stories/2008/05/25/2254836.htm (accessed December 16, 2008).

119 Hooper above note 1 at 243 .

120 As above at 266. 
Australian Legal Geography and the SEARCh For Postcolonial SpaCe in Chloe Hooper's

THE TALL MAN: DEATH AND LIFE ON PALM ISLAND

Doomadgee through to his acquittal and beyond. The themes of gender and sexuality sit just below the surface in The Tall Man. Hooper notes that the reason Hurley was in Dee Street the morning he killed Mulrunji was that he was accompanying indigenous woman Gladys Nugent to her house, at her request, so that she could collect her medication without the risk of being beaten again by Roy Bramwell, who had just beaten her and two of her sisters so badly that one of them had to be flown to Townsville hospital (that was the reason Roy Bramwell was in the police station when Hurley brought Mulrunji in) - Hurley was a white man protecting a brown woman from a brown man. ${ }^{121}$ Hooper goes on to profile Hurley in terms of his gendered and sexualised role as a white policeman in indigenous communities, and also reveals the police force itself to be a distinctly white patriarchal institution. Colonial relationships are gendered and sexualised ${ }^{122}$ - as scholars such as Andrea Smith have shown, the white masculine conquest of the feminised racial other goes far beyond the frontier rapes of brown women. It is welldocumented that white, colonising cultures are deeply patriarchal and misogynistic. As Irene Watson has argued, "Aboriginal women have become less safe the more the colonising project destroys Aboriginal laws and our women's spaces. We become less safe the more assimilated and shut into the "container" we have come to call home we get". ${ }^{123}$ In colonial relationships, the dominant white culture "administers and polices itself entirely within a patriarchal horizon". ${ }^{124}$ Native cultures and lands are feminised and seen as dirty, inherently violable and incapable of self-government, while deeply patriarchal institutions like the Queensland police force are charged with governing them. In The Tall Man, the white masculinity at the heart of that colonial, patriarchal relation appears to be what was at stake in Hurley's trial — like if he had been found guilty, the triumphant masculinity that Hooper captures in her descriptions of the police would have been damaged, and something fundamental about police-indigenous relations would be lost.

The colonial landscape within which Hooper situates Mulrunji and Hurley is one in which alcohol-fuelled violence by indigenous men against indigenous women is always highly visible. During the riot, Hooper writes that when Lex Wotton was demanding that the police leave the island, an older woman protested to him, "We want the police here. Who is going to protect us from you men if they go?" 125 While she is in Burketown, a local indigenous man tells Hooper that Hurley would have heard the "sounds of breaking furniture and slaps" from where he lived. ${ }^{126}$ And when Gladys Nugent is being cross-examined at Hurley's trial, Hooper describes her:

She'd been beaten before and would be again... Gladys stood for everything white Australians don't want to know about black Australia. She was alcoholic, diabetic, and she had heart troubles. She told the court about drinking all day and night, being beaten up,

121 Spivak above note 3 at 284 .

122 Smith Andrea Conquest: Sexual Violence and American Indian Genocide South End Press Cambridge MA 2005.

123 Watson Irene 'Aboriginal Women's Law and Lives: How Might We Keep Growing the Law?' (2007) 26 Australian Feminist Law Journal 95 at 103.

124 As above at 99.

125 Hooper above note 1 at 69.

126 As above at 131. 
drinking methylated spirits; about her partner Roy being in jail, about her nephew Patrick sniffing petrol and hanging himself. ${ }^{127}$

Whether or not white Australia wants to know about the lives of indigenous Australians in remote communities, the image of violence, addiction and despair in those communities is now a well-publicised one, having received significant media attention in white Australia, particularly since the Little Children are Sacred Report. What has received less public attention is the source of that violence, addiction and despair — the invasion and colonisation of Australia. Irene Watson has discussed how "the blow torch gaze" of white Australian media has focussed on sexual violence in indigenous communities, but has never turned back on its own society and laws, which fail to protect women from male violence. ${ }^{128}$ While The Tall Man does not explicitly discuss white misogyny and the persistence of violence against women in white culture, it does give a subtle and damning portrayal of white patriarchy in the police force and, by extension, in the white society on whose behalf it polices. By discussing the gendered violence in indigenous communities within the context of Australia's colonial geography, Hooper also acknowledges the colonial source of that violence. Indeed within the narrative of The Tall Man, Hurley, the Queensland police force, and the ongoing colonial project they are a part of, all become blurred into the white patriarchal violence of Australian law. Hurley is described as "the archetypal sheriff, clean-cut with deep-set dark eyes in a strong, handsome face, bristlingly physical and tall" 129 - a description of the heartthrob in a western film — white, male and overtly heterosexual. Hurley is "a man from a time when men had grit, and did not go to a gymnasium to get it". ${ }^{130}$ Hooper traces how Hurley played out this role as "a small town sheriff complete with deputy" while he was stationed in Burketown, and also discovers that he was a womaniser - he asked women to sit on his knee in the local pub, telling them they had to because he was a police officer, ${ }^{131}$ and there had been two sexual harassment complaints lodged against him earlier in his career. ${ }^{132}$ Pondering why Hurley decided so hastily to arrest Mulrunji that morning, Hooper wonders if "perhaps there was something about 'fucking queenie cunt' that got to him" earlier when Patrick Bramwell yelled abuse that appeared to question his sexuality. ${ }^{133}$

The Tall Man reveals how the institution of which Hurley is a part evinces the same white patriarchal values as he does. Hooper notes that when Hurley joined the force, police were still required to notify the Commissioner before they married or divorced; fathering "illegitimate" children was cause for dismissal, and just over 5 per cent of officers were women. ${ }^{134}$ Reviewing the initial investigation into Mulrunji's death, Hooper notes that Hurley and Robinson refer to each other with the familiar masculine nicknames "Hurls" and "Robbo". 135 The videotaped

127 As above at 217

128 Watson above note 123 at 100

129 Hooper as above note 1 at 19.

130 As above at 232

131 As above at 138 .

132 As above at 137.

133 As above at 22.

134 As above at 116

135 As above at 35. 
Australian Legal Geography and the SEARCh For Postcolonial SpaCe in Chloe Hooper's

THE TALL MAN: DEATH AND LIFE ON PALM ISLAND

interview between Hurley and the senior police investigating him "is striking for its camaraderie", with the senior officer referring to Hurley as "mate" and "buddy", and Hurley in turn calling him "boss". 136 They joke about not tearing the senior police officer's shirt as he and Hurley re-enact Hurley's version of how he dragged Mulrunji into the station minutes before his death. ${ }^{137}$ Hooper encounters this male camaraderie and sense of entitlement directly when she attends a Queensland Police Union meeting called to decide on protest action when it was announced that Hurley was to go to trial. Here Hooper finds the air "clammy with sweat and testosterone"; as part of the meeting she feels that "we were in a pack. We could feel each other's animal warmth and sweat and breath — and it made me shiver." 138 Despite Hurley's absence at that meeting, Hooper can sense him everywhere, "tall and dressed in righteous blue", she is "surrounded by him". 139

Hurley and his police force do seem to merge into one another throughout The Tall Man narrative - they share a sense of righteous indignation, a fierce determination to strike back at the judicial system they felt wronged by, and an unwavering refusal to consider that Mulrunji's death might have been criminal. While The Tall Man presents Hurley as part of the institutional space of the police force around him, it is also important to understand the police force as in turn part of the wider space of government policy towards indigenous Australia. The Queensland Police Union is not a rogue institution but the representative body of an executive arm of the state government. While Hoopers' descriptions of police officers' behaviour makes clear the patriarchal, racist, aggressive nature of the police force, police are no worse than the decades of repressive government policy towards indigenous Australians and those who create and benefit from that repression. When young white policemen like Hurley are sent into remote indigenous towns and become laws unto themselves - executing their own brands of summary justice, sleeping with local women and exerting their authority over these ex-mission towns - they are maintaining Australia's whiteness so that life for its "ordinary" citizens in the cities can continue free of the pesky issues of the nation's violent foundations.

When Hurley's friend Robinson addressed the Palm Island crowd after they had set fire to the police station, telling them that they had just "destroyed evidence against paedophiles", and that as such "they only have themselves to blame that they were letting sex offenders walk around in this community", ${ }^{140}$ his attitude was little different from those who were at that time creating the political justifications for the soon-to-be-announced Northern Territory intervention. Robinson's bemusement at the Islanders' response, "going into this stolen generation thing...you know, and I'm shaking my head, in fucking disbelief that they're bringing up that shit at this time", ${ }^{141}$ could be read as a crude articulation of then Prime Minister Howard's attitude towards indigenous policy issues. Robbo and Hurls, like the frontier men who preceded them, are lowranked public servants executing Australia's policies of conquest and colonisation.

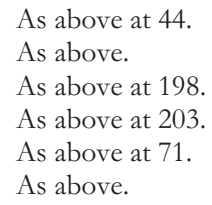


The Tall Man paints a vivid yet complex picture of the police patriarchy and its vitriolic reaction at having its power to kill indigenous Australians threatened. Then Queensland Police Union President Gary Wilkinson was found guilty of contempt of court for his public statements that Coroner Christine Clements' findings that Hurley had caused Mulrunji's death were the result of her "witch-hunt" of an inquest which "she approached... as a foregone conclusion" despite evidence that "she deliberately overlooked." 142 While the twisted gender connotations of the "witch-hunt" insult against Clements may have been coincidental, it seems likely that the president of a deeply patriarchal institution was particularly susceptible to a vitriolic outburst against a judicial figure who not only dared to criticise his institution but also bore the unusual feature of being a woman. The QPU launched a campaign selling blue wristbands printed with Hurley's police badge number, which were available for $\$ 5$ at any Queensland police station. ${ }^{143}$ In the QPU journal, the promotional image for the wristband campaign features a young policewoman raising her arm - almost Rosie the Riveter style - to show her wristband to the camera, ${ }^{144}$ and Hooper notes that a similar image appeared on the front page of the south Queensland newspaper the Gold Coast Bulletin. ${ }^{145}$ This very public promotional image of a policewoman seems a tokenistic gesture aimed at portraying the Queensland police force as something other than a patriarchal institution, to counter the bully-ish image it was gaining from the less measured, aggressive outbursts of the QPU's all male spokespeople. When the prosecution lawyer finished his final argument to the jury, summing up the damning evidence against Hurley, Hooper observes that for a moment Hurley's mask cracked, his bottom lip quivered, and "all the bravado of the union men evaporated." "146 When the jury returned the not guilty verdict, the union launched a series of radio, television and newspaper advertisements that Hooper accurately describes as "high-rotation gloating." 147 Hurley, the Queensland police force, and white patriarchal authority itself had had their colonial authority to kill Aborigines with impunity momentarily questioned, but they had come through victorious and now reacted like spoilt school boys. Although Mulrunji's death has not been publicly or academically discussed in terms of gender or sexuality, the details of police behaviour in The Tall Man make it clear that Queensland police attitudes are still institutionally patriarchal as well as colonial, and more broadly that Australia's colonial space is still maintained through systems of patriarchy.

\footnotetext{
142 Watt Amanda "Police boss found guilty" (18 March 2007) available at http://www.news.com.au/couriermail/ story/0,23739,21405838-952,00.html (accessed 28 December 2008).

143 “True Blue Support" (February 2007) Police Journal: Official Publication of the Queensland Police Union p 24.

144 As above.

145 Hooper above note 1 at 204

146 As above at 258

147 As above at 265 .
} 
Australian Legal Geography and the SEARCH For PostColonial SPACE IN CHLOE HoOper's

THE TALL MAN: DEATH AND LIFE ON PALM ISLAND

\subsection{Postcoloniality: THe Impossibility OF LAW AND THE PossibILITY OF SOMETHING ElSE}

The Tall Man demonstrates Australia's failure to move to a space of postcoloniality, highlighting the way in which the Australian legal system continues to reproduce the landscape created by the original violence of the colonial invasion. That landscape is one in which indigenous people are systematically dispossessed from their land and their culture, and where white patriarchal institutions such as the Queensland police force are legitimated because without them the landscape could not be maintained. The place that is Australia today is a place that requires ongoing practices of colonial dispossession - practices that are enforced by police in remote areas but that all of white Australia benefits from and is responsible for. The Tall Man demonstrates how the intertwining of particular histories and persistently colonial understandings in Australia mean that indigenous Australians are still out of place as anything other than defendants and native title claimants in Australian courtrooms. Those courtrooms are spaces of whiteness - spaces that do not hold up indigenous bodies, spaces where resources such as private legal representation, pressed suits, confidence in public speaking and quick comebacks to cross-examination are not within their reach. Apart from her descriptions of the painful out-ofplace-ness of the indigenous witnesses at both the inquest and the trial, and her mapping of the wider inequalities between Hurley's white and Mulrunji's black Australia, Hooper also notes that 17 out of the 18 lawyers at the inquest were white, 148 and that Palm Islanders were not surprised when the inquest stalled, because "white law was like that". ${ }^{149}$ That white space of Australian law never grasped or did justice to the wrong done to Mulrunji, because he was understood as belonging to a different space - one of indigeneity, alcoholism and violence. The Tall Man leaves readers with a palpable sense of injustice, in respect of Mulrunji's death and of the way the law handled it.

Hooper's book is not, however, without glimmers of hope that Australian postcolonial space is possible. She searches for, and indeed attempts to create in The Tall Man, a space of postcoloniality outside of law; a space that is not as incandescently white as she finds the legal system to be - a space that is capable of recognising non-white standpoints and of holding up indigenous bodies. Hooper does this through her unique style of narration in The Tall Man, which weaves together indigenous and non-indigenous ways of knowing and understanding the world - though always inevitably refracted through Hooper's non-indigenous lens. The Tall Man is at the same time the narrative of a white woman witnessing the aftermath of Mulrunji's death in custody on Palm Island, and an account of the indigenous story of the Tall Man, which I will explain further below. It fuses indigenous "mythology" together with English (language) narrative, and in doing so it makes indigenous knowledge real and contemporarily relevant rather than stuck in a primitive past as white culture suggests and white law requires. ${ }^{150}$ The Tall Man frequently includes mention and explanation of indigenous knowledge, including Dreamtime

148 As above at 89.

149 As above at 103

150 see Motha above note 89. 
stories, ${ }^{151}$ the Gulf Country peoples' understanding and terminology for the white invasion ("Wild Time"), ${ }^{152}$ and the purpose of particular cave paintings. ${ }^{153}$ Hooper does not just summarise these excerpts of indigenous knowledge, but playfully yet respectfully ponders how that knowledge might apply to her and those around her. When an indigenous man takes Hooper fishing near Burketown and they fail to catch many fish, "he complained about a man who had come fishing with money in his pocket so no one had caught anything. I had a credit card in mine and wondered if it was my fault". ${ }^{154}$ Setting out the history and current political situation of Palm Island, she writes that "on Palm Island live refugees from Wild Time; they live cut off from the religion and culture of their traditional lands". ${ }^{155}$ Putting together in one short phrase a familiar category of white legal and political discourse and a little-known indigenous term for the white invasion of Australia, Hooper's writing here draws with equal respect from indigenous and white knowledge and uses them together to discursively produce something new — an understanding that might be considered postcolonial.

This fusing together of indigenous and non-indigenous knowledge is enabled by the unique genre of Hooper's book. Classified by the publishers as "true crime" the book takes the form of a novel and has won a number of popular awards, 156 appealing to an audience that might not normally be interested in reading about indigenous deaths in custody. The most famous nonfiction novel/true crime book is Truman Capote's In Cold Blood, published in 1965 - another book about law and homicide, and like The Tall Man, also preceded with a series of journalistic style articles in a magazine (The New Yorker) before the full length novel. The genre straddles the line between journalism and the (usually fiction) novel, meaning that, as discussed above, the writer is dealing with real life people without being bound to a professional code of conduct as journalists are. This liberty carries the danger of giving the writer scope to potentially divert from the truth, but it also allows the writer to challenge popular conceptions of the truth on a deeper, more affective level than straight journalistic or policy work can. Hooper's beautifully written narrative captures the emotion of the trial and the coronial inquest in a way that academic and journalistic accounts cannot. As a non-fiction novel, The Tall Man is able to communicate to readers both the "hard facts" of what happened and the emotion that results from those facts at a level of detail usually reserved for academic studies but in a format that reaches far beyond an academic audience.

Hooper weaves together indigenous and white understandings most powerfully in her telling of the indigenous story of the Tall Man. Hooper is first introduced to the Tall Man by a couple of Palm Island teenage boys - she describes the Tall Man as "the island's combination of Big Foot and the bogie man". ${ }^{157}$ One of the boys pointed to a nearby light-post to show the Tall Man's height, explaining that he had giant feet and red eyes that could be seen in the dark.

151 Hooper above note 1 at 53.

152 As above.

53 As above at 2.

154 As above at 138

155 As above at 56; emphasis added.

156 Including a New South Wales Premier's Literary Award.

157 Hooper above note 1 at 59. 
Australian Legal Geography and the SEARCh For Postcolonial SpaCe in Chloe Hooper's

THE TALL MAN: DEATH AND LIFE ON PALM ISLAND

Hooper's research finds that Tall Man stories exist all over indigenous Australia, all of them representative of towering evil. ${ }^{158}$ Against this description, Hooper recounts the court statements of Palm Island residents who were witnesses to Hurley's arrest of Mulrunji - Roy Bramwell had said of Hurley, "he tall, he tall, he tall, you know" and another had stated "the tall man get out and arrest him. I saw the tall man grab him by the arm". ${ }^{159}$ The suggestion that the Tall Man story is not just an indigenous myth but an Australian reality begins with statements that suggest Hurley is the Tall Man to Palm Islanders, and is extended though Hooper's constant descriptions of Hurley as a tall man. When Roy Bramwell demonstrated to the coroner what he had witnessed Hurley do to Mulrunji in the police station, Hooper could suddenly "see it all clearly: a big tall man's knee pressed on the chest of someone pinned against a concrete floor". ${ }^{160}$ When the inquest resumed after a break of several months, Hooper describes seeing Hurley again: "here he was — tall, dark, classically handsome". ${ }^{161}$ Her descriptions of his impressive height fit with her portrayal of his white masculinity as discussed in the previous section. At Hurley's trial, Hooper describes Hurley fidgeting in the dock — "It seemed hard to keep that body still. All that flesh and bone, all that weight and strength... It's a mixed blessing, being so big." 162 When Hurley was called as a surprise witness in the trial, Hooper describes him standing and walking to the witness box, where "he towered over the bailiff". ${ }^{163}$ At seven foot, there is no doubt that Hurley is a tall man, but through Hooper's narrative, she gradually reveals to her non-indigenous readers that Hurley is a Tall Man. This materialisation is powerfully completed in the final lines of the book, in which Hooper observes Hurley at a "Pride in Policing" rally held in his honour in Brisbane. She watches him performing the role of a white patriarch at home, playing with "a little blonde girl" - growling at her like a monster while she squeals in delight, and at that point the indigenous myth crystallises as reality for Hooper - "There he was, the Tall Man". ${ }^{164}$ When she looks again she cannot find him, because he had "dissolved into a long stream of blue" 165 — thus relocating Hurley within the wider space of Tall Men who make up the Queensland Police Force. Here at the end of the book, Hooper is haunted by real life Tall Men, the same Tall Men who torment indigenous Australians on a daily basis. This fusing of indigenous and white knowledge arguably creates a space of postcoloniality, because it introduces an understanding that is distinctly different from its colonial predecessors which placed white knowledge firmly above indigenous knowledge.

At the same time as it shows the reality of indigenous lore, The Tall Man also shows the mythological side of white law, which in white Australia is generally assumed to be secular and rational. Hooper's descriptions of the criminal and coronial inquiry proceedings convey the feeling that those proceedings do not perform rational, dependable calculations of justice and

\footnotetext{
As above at 84 .

As above at 60 .

As above at 101 .

As above at 153 .

As above at 224 .

As above at 228 .

4 As above at 266.

5 As above.
} 
truth, but rather perform something more mystical. Describing the lawyers' examination of Bengaroo during the Townsville courthouse hearings, Hooper writes that "once or twice Bengaroo seemed on the verge of saying more, but each time, by chance someone in the court coughed or shuffled and some spell was broken". ${ }^{166}$ Is the white legal system really so feeble and uncertain as for its results to be susceptible to the influence of a cough or shuffle in the courtroom? Is the extraction of truth from a witness comparable or even equivalent to putting that witness under some kind of spell? The story of the coronial inquiry into Mulrunji's death in custody and the trial of Chris Hurley would suggest so. The ritualistic procedures and costumes worn by those participating in courtroom processes would make any sorcerer envious, and the mystical foundations of white law have been thoroughly explored before. ${ }^{167}$ The Tall Man explores some of the manifestations of that mystique in today's Australian courtrooms. When the defence cross examination of Hurley during his trial fails to catch him out as he self-righteously and defiantly repeats his version of the story, Hooper writes that "he was like an evasive spirit, hiding in the legal cracks... Each new proceeding claimed to be the place where the truth would be known, the shadows cast out, the bright light of justice triumph".168 But of course, each proceeding failed. The white magic of legal spaces does not work for indigenous Australians. Hooper's exposition of the mythological side of white law does not read as a prima facie critique of that law - for it to do so would be to slip back into the implicitly racist reasoning that everything rational and secular is good and everything mystical or mythological is bad. Instead, her account of the mystic and mythological nature of white law resonates with her account of the reality and relevance of indigenous lore. Both angles contribute to The Tall Man's production of a narrative that is neither completely white nor completely indigenous but that is a genuine attempt at a postcolonial meeting of both.

I say attempt because although The Tall Man is undoubtedly a work of great significance in postcolonial Australian literature, it is not without its problems. Hooper occasionally slips into language and comparisons that reproduce, uncritically, some of the ideas upon which Australian racism against its indigenous population is built. She refers at several stages to Joseph Conrad's Heart of Darkness, ${ }^{169}$ asking herself "what if... fighting a war against savagery, you become a savage yourself". ${ }^{170}$ While her comparisons of today's police officers in remote Australia to missionaries in the same areas are potent, it is at times unclear whether she is implicitly suggesting that savagery and violence originate in native communities or in the colonial project itself. Colonial violence, whether it takes place in the Congo or in remote Australia, is just that — the violence of the coloniser. It is well documented that violence is inherent in the colonial project rather than in native communities. ${ }^{171}$ In her poignant descriptions of the characters involved in Mulrunji's death

166 As above at 152

167 Most significantly in Benjamin Walter "Critique of Violence" in Reflections: Essays, Aphorisms, Autobiographical Writings Schocken Books New York 1978 at 277 and Derrida Jacques "Force of Law" in Acts of Religion Routledge New York 2002 at 230, but also in many other rich and continuing conversations about political theology.

168 Hooper above note 1 at 237.

169 For example at pages 81-82 and 119 as above.

170 Hooper above note 1 at 119.

171 See Smith Andrea above notes 97 and 122 and Watson Irene above notes 79 and 123 as well as Fanon Frantz The Wretched of the Earth Penguin Harmondsworth 1985. 
Australian Legal Geography and the SEARCh For Postcolonial SpaCe in Chloe Hooper's

THE TALL MAN: DEATH AND LIFE ON PALM ISLAND

and its aftermath Hooper also seems to occasionally overstep her claims. When describing Lex Wotton's role in the riots for example, Hooper claims that he turned off the water before the police station was set alight, a claim denied by Wotton himself ${ }^{172}$ and discarded in court. ${ }^{173}$ The book also lacks any warning that it contains descriptions and photos of deceased indigenous people - content which is perhaps obvious from the book's title but which nonetheless warrants warning to potential indigenous readers who may observe avoidance practices and/or be upset or offended by the naming and reproduction of descriptions and images of deceased indigenous people. Overall though, The Tall Man is a powerful book that captures in gripping prose the undiscussed details of Mulrunji's death in custody and the legal proceedings that followed (and indeed continue to follow ${ }^{174}$ ) it. Rather than jumping to conclusions or demonising any of the characters, the book maps the colonial legal geography of Australia and locates the characters within it. Hooper's intertwining of the indigenous story of the Tall Man into her own, selfconsciously white narrative of the legal proceedings is an original and productive attempt to create a space of Australian postcoloniality where the Australian legal system could not.

172 Lex Wotton on Palm Island (2008) produced and directed by Anthony Snowden and available at http://www.engage media.org/Members/d4nlaurence/videos/Wotton1.mp4/view accessed 4 January 2009.

173 R v Lex Patrick Wotton (7 November 2008) Queensland District Court Townsville Sentencing Remarks per Judge Shanahan.

174 At the time of writing, Hurley has successfully won an unprecedented application to the District Court of Queensland to overturn Coroner Clements' report and open a new inquiry (Hurley v Clements \& Ors [2008] QDC 323). An appeal against this decision launched by Boe Lawyers on behalf of the Doomadgee family was heard by the Queensland Court of Appeal on May 25-26, 2009, with judgement currently still reserved. 